\title{
Т.А. Алпатова
}

Московский государственный областной университет, 141014 г. Мытищи Московской области, Российская Федерация

\section{Путь к пониманию себя... (образ поэта и осмысление поэзии в русской лирике XVIII века)}

Аннотация. Цель статьи - проанализировать ранний этап становления образа поэта и художественного представления поэзии в русской лирике середины XVIII века. На примере творчества М.В. Ломоносова, стихотворения «Разговор с Анакреонтом», охарактеризована специфика поэтологических деклараций в литературной теории русского классицизма. «Разговор с Анакреонтом» Ломоносова проанализирован как целостный текст; мотивы, которые его объединяют, представляют концепцию поэта и поэзии, положенную в основу последующего развития российской поэтологической лирики.

Ключевые слова: русский классицизм, поэтологическая лирика, поэтологическая декларация, литературная теория

\section{T.A. Alpatova}

Moscow Region State University, Mytishi, Moscow Region, 141014, Russian Federation

\section{The way to understanding oneself... (image of the poet and concept of poetry in Russian lyrics of the XVIIIth century)}

\begin{abstract}
The purpose of the article is to analyze the early stage of forming the image of the poet and the artistic representation of poetry in Russian lyrics of the mid-18th century. On the example of the work by M.V. Lomonosov's, the poem "Conversation with Anacreon", the specificity of poetological declarations in the literary theory of Russian classicism is characterized. "Conversation with Anacreon" by Lomonosov is analyzed as a holistic text; the motives, that unite it, represent the concept of poet and poetry, which laid the foundation for the subsequent development of the Russian poetological lyrics.
\end{abstract}

Keywords: Russian classicism, poetological poetry, poetological declaration, literary theory 